See discussions, stats, and author profiles for this publication at: https://www.researchgate.net/publication/316595685

First Record of Lutzomyia (Lutzomyia) longipalpis (Diptera: Psychodidae: Phlebotominae) on the Trinational Frontier (Brazil-Peru-Bolivia) of SouthWestern Amazonia

Article · April 2017

DOI: $10.1093 / \mathrm{jme} / \mathrm{tj} \times 086$

6 authors, including:

Mara Pinto

São Paulo State University

35 PUBLICATIONS 375 CITATIONS

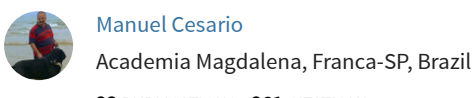

23 PUBLICATIONS 261 CITATIONS

SEE PROFILE

SEE PROFILE

ล. Dennys Ghenry Samillan Ortiz

University of Campinas

4 PUBLICATIONS 7 CITATIONS

SEE PROFILE

Some of the authors of this publication are also working on these related projects:

Climate Change and Health View project

Estudo de aspectos biológicos de Nyssomyia neivai (Diptera: Psychodidae) e aprimoramento das técnicas de colonização em laboratório View project 


\title{
First Record of Lutzomyia (Lutzomyia) longipalpis (Diptera: Psychodidae: Phlebotominae) on the Trinational Frontier (Brazil-Peru-Bolivia) of South-Western Amazonia
}

\author{
Diones Antonio Borges, ${ }^{1, *}$ Silvia Maria Guerra Molina, ${ }^{1}$ Mara Cristina Pinto, ${ }^{2}$ Eunice \\ Aparecida Bianchi Galati, ${ }^{3}$ Manuel Cesario, ${ }^{4}$ and Dennys Ghenry Samillan Ortiz ${ }^{5,6, *}$
}

1Department of Genetics, Luiz de Queiroz College of Agriculture (ESALO) - University of São Paulo (USP), Piracicaba, São Paulo, Brazil (dionesborges@hotmail.com; silviamgmolina@usp.br), ${ }^{2}$ School of Pharmaceutical Sciences (FCF), State University (UNESP), Araraquara, São Paulo, Brazil (marap@fcfar.unesp.br), ${ }^{3}$ Department of Epidemiology, School of Public Health, São Paulo State University (USP), São Paulo, São Paulo, Brazil (egalati@usp.br), ${ }^{4}$ Magdala Science and Sustainability, Franca, São Paulo, Brazil (manuel.cesario@uol.com.br), ${ }^{5}$ Department of Animal Biology, Institute of Biology, State University of Campinas (UNICAMP), Campinas, São Paulo, Brazil (d162706@dac.unicamp.br), and ${ }^{6}$ Corresponding author, e-mail: d162706@dac.unicamp.br

*These authors contributed equally to this work.

Subject Editor: Richard Johnson

Received 11 January 2017; Editorial decision 28 March 2017

\begin{abstract}
In South America, the main sand fly species involved in the transmission of Leishmania infantum chagasi (Cunha \& Chagas, 1937), etiological agent of the visceral leishmaniasis (VL), is Lutzomyia longipalpis (Lutz \& Neiva, 1912). The species has been recorded in Colombia, Venezuela, Bolivia, Argentina, Paraguay, Uruguay, and Brazil, where it is recorded in 24 of the 27 Brazilian states, except Acre, Amazonas, and Santa Catarina. Collections were carried out for one year (April 2013 to March 2014) using modified CDC light traps in different environments in Assis Brasil municipality, state of Acre. Two males of Lu. longipalpis were found in peridomiciliary location in a periurban area. This is the first record of the species in Acre. This finding may be considered by the health agencies located in the trinational frontier, and new collections are needed to evaluate the real distribution of the species.
\end{abstract}

\begin{abstract}
Resumo
Na América do Sul, a principal espécie de flebotomíneo envolvido na transmissão de Leishmania infantum chagasi, agente etiológico da Leishmaniose visceral (VL), é Lutzomyia longipalpis (Lutz \& Neiva, 1912). Esta espécie já foi registrada na Colômbia, Venezuela, Bolívia, Argentina, Paraguai, Uruguai e Brasil, onde foram registradas em 24 dos 27 estados brasileiros, com exceção do Acre, Amazonas e Santa Catarina. As coletas foram realizadas por um ano (abril de 2013 a março de 2014) utilizando-se armadilhas de luz tipo de CDC em diferentes ambientes no município de Assis Brasil, estado do Acre. Dois machos de Lu. longipalpis foram encontrados no peridomicílio de uma residência localizada na área periurbana, sendo o primeiro registro desta espécie no estado. Esse achado deve ser considerado pelas agências de saúde localizadas na fronteira trinacional. Novas capturas serão necessárias para avaliar a distribuição real da espécie.
\end{abstract}

Key words: visceral leishmaniasis, sand fly, spacial distribution, monitoring, Acre

Literature data point out that 528 sand fly species are recorded in Americas (Shimabukuro et al. 2017); Lutzomyia longipalpis (Lutz \& Neiva, 1912) stands out as the main vector of Leishmania (Leishmania) infantum chagasi, the etiologic agent of visceral leishmaniasis (VL). The epidemiological relevance of this disease consists in its lethality if not treated, and also because there is as yet no available vaccine (Pan American Health Organization [PAHO] 2016).

Brazil is of fundamental importance in the epidemiology of $\mathrm{VL}$ because, along with Argentina and Paraguay, the area in it of the transmission of the disease is spreading, and also because from 2001 to 2014 , of the 48,720 cases of VL registered in the Americas, 46,976 of them $(96.42 \%)$ were concentrated in Brazil (PAHO 2016).

The spread of Lutzomyia longipalpis in Brazil, from rural to urban areas, has been well documented over time (Lainson and Rangel 2005, Brazil 2013). This species has already been found in 27 Brazilian states (Rangel and Vilela 2008, Souza et al. 2009, Santos et al. 2012, Galardo et al. 2013). 


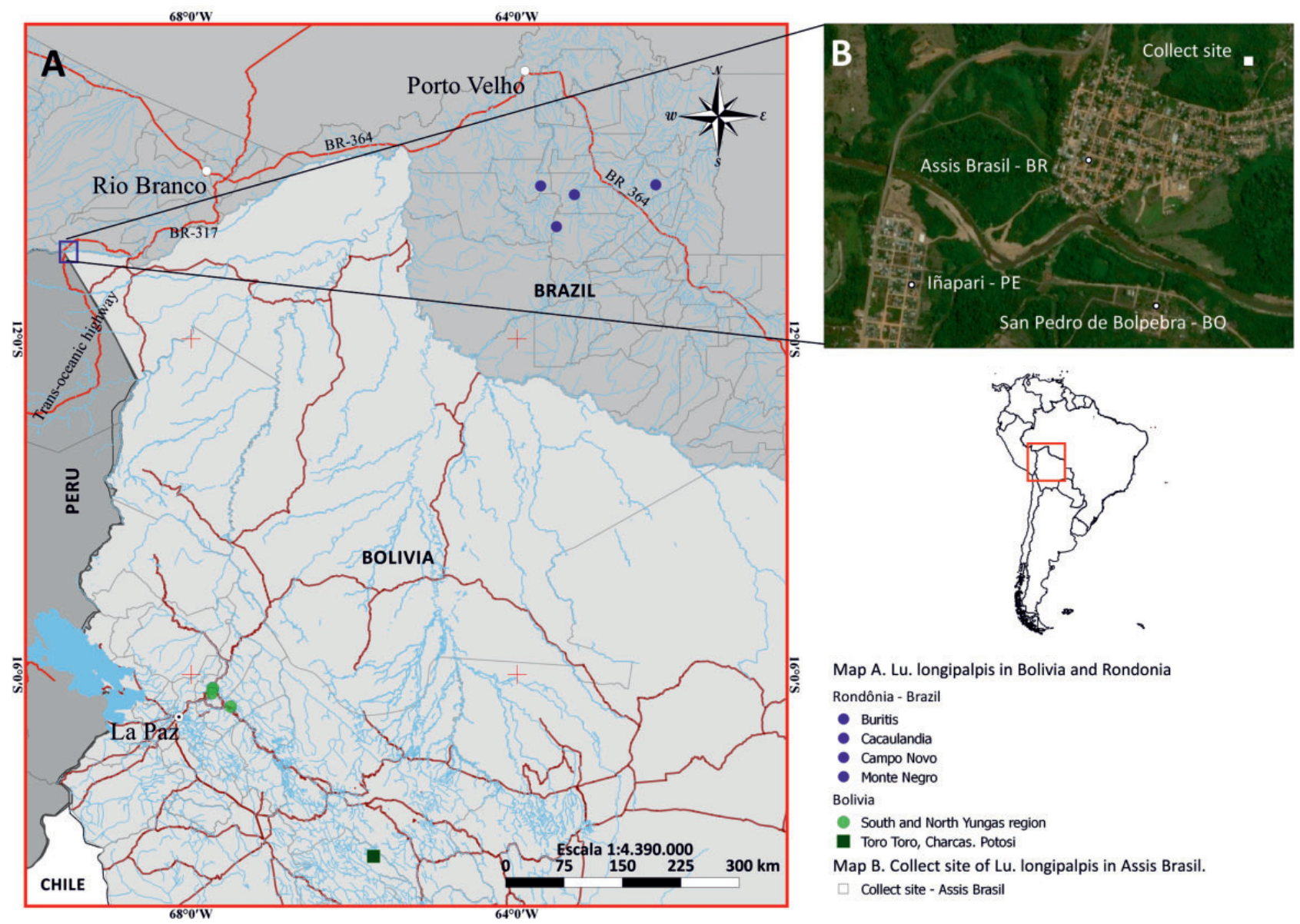

Fig 1. Distribution of Lu. longipalpis in Acre and neighboring places. Map A. Sites with the presence of Lu. longipalpis in Bolivia and Rondonia, Brazil. Map B. Site $\left(10^{\circ} 56^{\prime} 12.541^{\prime \prime} \mathrm{S} / 69^{\circ} 33^{\prime} 29.999^{\prime \prime} \mathrm{W}\right)$ with the presence of Lu. longipalpis in Assis Brasil, Brazil.

Acre state presents a high coefficient of detection of American tegumentary leishmaniasis (ATL) whose etiology has been attributed to various species of Leishmania (Secretaria de Vigilância em Saúde [SVS] 2007). Such epidemiological scenario has motivated several researchers to undertake projects to investigate the phlebotomine fauna with a view to identifying possible vectors. Data from the literature indicate that Acre presents a great diversity of species, by the end of 2008, 52 species had been reported (Azevedo et al. 2008); later 16 new records (Teles et al. 2013a, 2016) and three new species (Teles et al. 2013a, De Oliveira et al. 2015, Brilhante et al. 2017) were reported, with a total of 71 species of sand fly. However, Lu. longipalpis had not previously been found in this state, even in captures in rural areas of Assis Brasil (Teles et al. 2016).

\section{Materials and Methods}

\section{Study Area}

The Brazilian municipality of Assis Brasil lies on the triple BrazilPeru-Bolivia border in the South-Western Amazon, in the southwest of the State of Acre $\left(10^{\circ} 56^{\prime} 27^{\prime \prime} \mathrm{S}\right.$ and $\left.69^{\circ} 34^{\prime} 4^{\prime \prime} \mathrm{W}\right)$, being located on the left bank of the Acre River (Fig. 1). It occupies a total area of $4,974.175 \mathrm{~km}^{2}$ that represents $3.03 \%$ of the territory of the Acre State. It has a population of 6,072 inhabitants, of which whom $39.1 \%$ live in the rural area, and has a Municipal Human Development Index (MHDI) of 0.601 (Secretaria de Estado de Planejamento do Acre [SEPLAN] 2013, Instituto Brasileiro de Geografia e Estatística [IBGE] 2016). The vegetation is of the open forest type with bamboo and palm trees and dense ombrophilous forest (Secretaria de Estado de Meio Ambiente do Acre [SEMA] 2010); the average annual temperatures in the State range from $24.5^{\circ} \mathrm{C}$ to $32^{\circ} \mathrm{C}$, the relative humidity is around $90 \%$, and the annual rainfall varies from $1,600 \mathrm{~mm}$ to $2,750 \mathrm{~mm}$ (Acre 2016).

The entomological collections were carried out in the municipality of Assis Brasil from April 2013 to March 2014, with modified CDC light traps (Pugedo et al. 2005) in five consecutive nights. The traps were set up in the intradomiciliary and peridomiciliary environment and in the forest adjacent to four houses, one of which located in the urban area, two in a peri-urban environment, and one in a rural area. The traps were installed at $1.50 \mathrm{~m}$ above from the ground from 6 p.m. to 6 a.m. for five consecutive nights, in the phase of the moon known as the New Moon. Altogether, 60 catches were carried out in each of the environments. All traps were new and used for the first time in this study.

The specimens were sexed and preserved in plastic flasks containing naphthalene, until their maceration in accordance with the technique described by Forattini (1973). Then they were mounted in Balsam of Canada and identified, as proposed by Galati (2016).

\section{Results}

In the areas sampled, a total of 22,334 sand flies were collected10,733 males $(48.1 \%)$ and 11,601 females $(51.9 \%)$. In the peri-urban areas 14,805 specimens were captured, giving an average of 41.1 


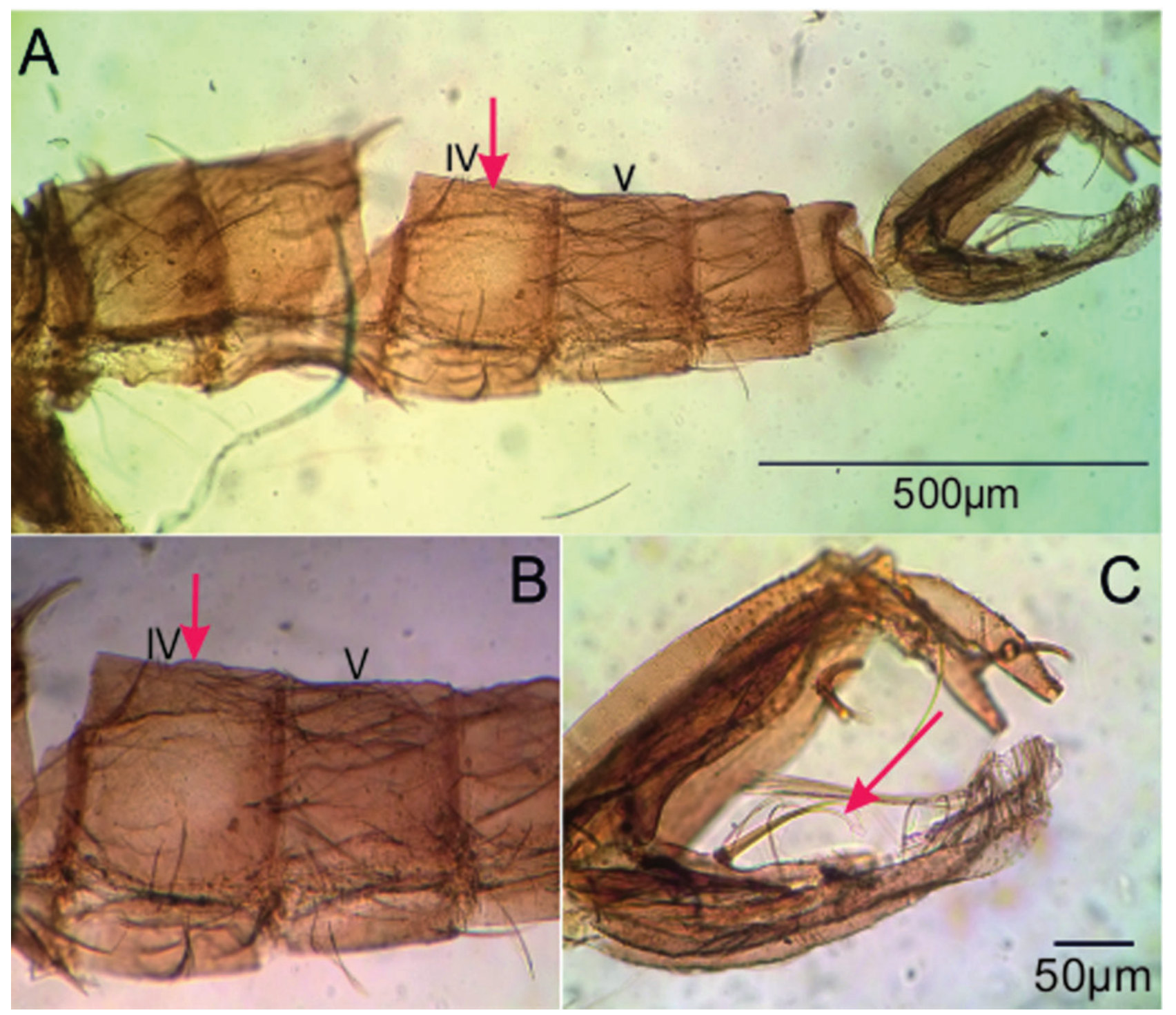

Fig 2. Abdomen and male genitalia of Lu. longipalpis. (A) Pale patches containing tergal papillae in the fourth abdominal tergite (arrow). (B) Fourth abdominal tergite amplified (arrow). (C) Bristles with curved, hooked apex on the dorsal margin of the paramere (arrow).

insects per trap; in the rural area 7,424 (41.2 insects per trap) and in the urban area 105 (0.6 insects per trap). Of the total number of sand flies caught, 18,033 insects $(80.7 \%)$ were captured in the forested environment, $3,495(15.5 \%)$ in the peridomiciles, and $806(3.6 \%)$ indoors.

Only two Lu. longipalpis males were captured (on the same night) in a peridomicile located in the peri-urban area of Assis Brasil - AC. (Fig. 2). The total of sand fly fauna will be published in a future paper.

\section{Discussion}

The two specimens of Lu. longipalpis were collected in May 2013, in the peri-urban region, in the peridomiciliary environment (Fig. 3), characterized by the cultivation of vegetables, the presence of trees such as the banana plant (Musa spp.), acerola (Malpighia emarginata DC), cashew (Anacardium occidentale L), and cupuaçu (Theobroma grandiflorum Schum). In addition, there are domestic animals such as dogs and fowl (chickens and ducks). In the environment, there is no structured chicken coop and the chickens use the trees for shelter. This environment is consistent with several studies which report the presence of $L u$. longipalpis in peridomiciles due to this sand fly's attraction to hens and dogs as food source, with the possibility of the circulation of Leishmania spp. between insect vectors and mammal hosts (Alexander et al. 2002, Sant'Anna et al. 2010).

The opening of new areas of human occupation through Land Use and Cover Change, especially in south-western Amazonia (which embraces the Brazilian states of Acre, Rondônia, western part of Amazonas; Madre de Dios Department-Peru; Pando Department-Bolivia) has led to the expansion of the transmission area of ATL (Luna 2002, Cesario and Andrade-Morraye 2008, Mooney et al. 2009, Cesario et al 2011). Acre has been reported to have 20 times higher incidence rates (coefficient of detection) of ATL than the level considered as "very high transmission" by the Brazilian Ministry of Health (SVS 2007, Secretaria de Ciência e Tecnologia e Insumos Estratégicos [SCTIE] 2010).

There are probably two possible routes of vector dispersion: from Bolívia (in the Yungas region and the municipality of Toro Toro in Potosi; Le Pont and Desjeux 1985, Le Pont et al. 1989, Dujardin et al. 1997, Garcia et al. 2009) or from Rondônia Brazilian state (in the municipalities of Cacaulândia, Monte Negro, Buritis, and Campo Novo; Gil et al. 2003, Teles et al. 2013b; Fig. 


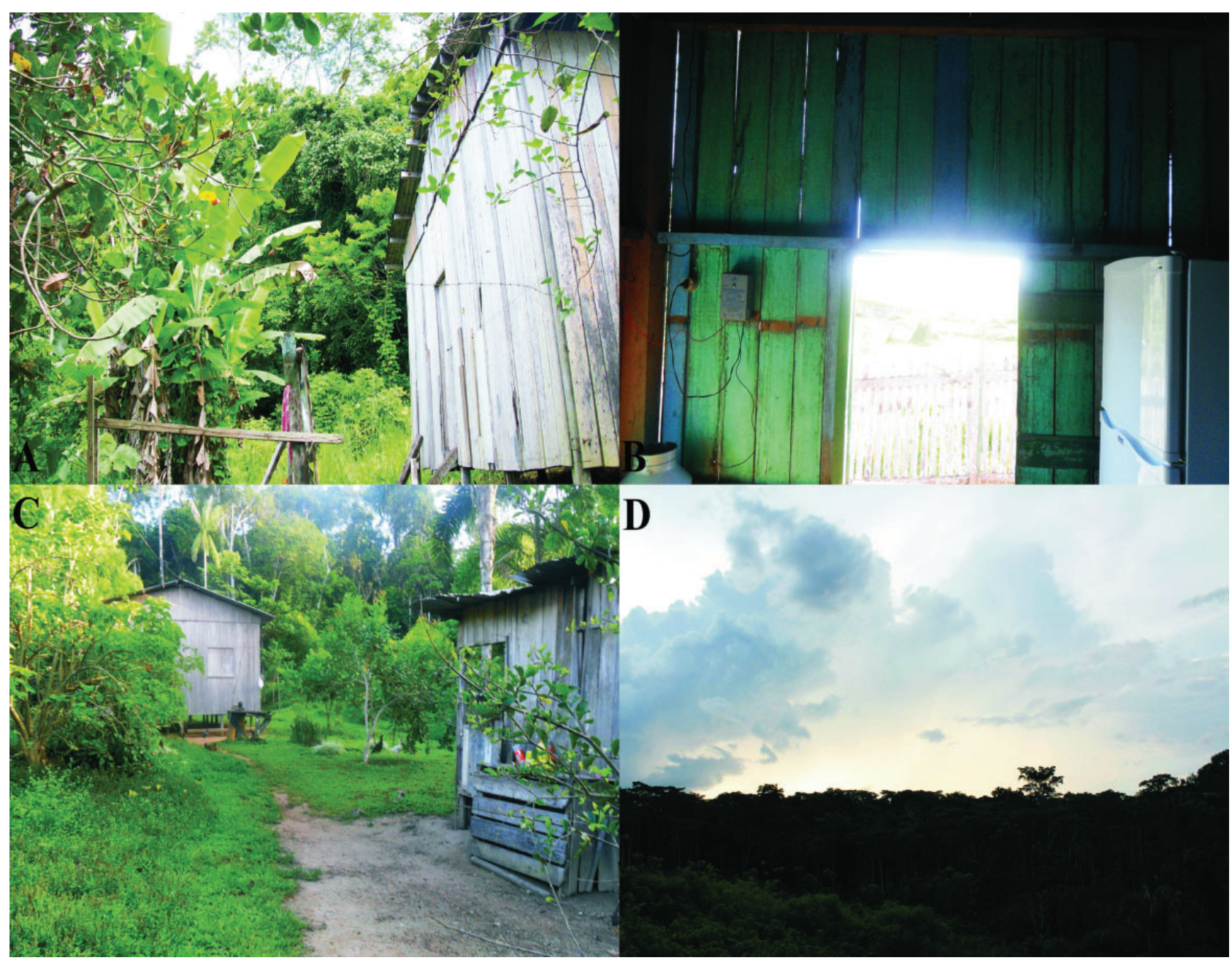

Fig 3. Sand flies sampling sites. (A) Typical wood-built domicile located in the peri-urban region of the Assis Brasil. (B) Presence of holes on the walls and the floor. (C) Peridomicile with forest adjacent (trees) and domestic animals (collect site of Lu. longipalpis). (D) Secondary forest adjacent to the sampling site in Assis Brasil.

1). The distances from Assis Brasil and the nearest places where $L u$. longipalpis was collected in Bolívia and Brazil is almost the same, roughly $600 \mathrm{Km}$, but Bolivia presents the highest altitudes (9502,800 AMSL) compared to Brazil (190 AMSL). New entomological captures will be necessary to arrive at a better understanding of the dispersion of this species in the region.

In addition, other studies, such as the biological cycle (Souza et al. 2009), sexual pheromone analysis (Hamilton et al. 2005), and males' mating sound (De Souza et al. 2002) would be opportune to clarify the relation of the Lu. longipalpis population from Assis Brasil with other allopatric populations.

According to the classification of the areas of Visceral Leishmaniasis Control Program of the Brazilian Ministry of Health, the municipality of Assis Brasil could be classified as a silent area (where no autochthonous cases of VL have been reported), receptive (with the confirmed presence of $L u$. longipalpis), and vulnerable (with intense migratory flow, especially as it is a border area with Peru and Bolivia; SVS 2006).

The relevance of this register is justified as an alert for government health agents, since the Brazilian Ministry of Health establishes the following recommendations for silent and receptive areas: environmental sanitation, control of the wandering canine population, and survey of canine serological sampling (SVS 2006).

Due to the proximity of the Brazilian municipality of Assis Brasil to Peru and Bolivia, a greater evaluation of the risk of the dispersion of Lu. longipalpis in these bordering countries as the possibility of the appearance of the disease in the future is to be recommended.

\section{Acknowledgments}

We thank Dr. Marco Tulio Antonio Garcia-Zapata for all helpful suggestion and discussions. We also thank the support received in Assis Brasil, provided by the Municipal Health Secretariat, by the Chico Mendes Institute for Biodiversity Conservation (ICMBio), and the various citizens that allowed and permitted our work in their households, in Assis Brasil, Acre, Brazil, for the support received. We are grateful to $\mathrm{CNPq}$ (National Council for Scientific and Technological Development Fellowship \#140363/2015-7) and CAPES (Coordination for the Improvement of Higher Education Personnel), by the scholarships for the doctorate in the respective programs, Animal Biology (UNICAMP) and Apllied Ecology (inter-unit USP/ESALQ and CENA). The entomological collections were made possible through the FAPESP (São Paulo Research Foundation) Thematic Grant 08/58.156-8 and the SNIS trinational "Andes-Amazon" grant.

\section{ReferencesCited}

Acre 2016. O Estado do Acre. Governo do Estado do Acre, Rio Branco.(http:// www.ac.gov.br/wps/portal/acre/Acre/estado-acre) (accessed12 October 2016). 
Alexander, B., R. L. de Carvalho, H. McCallum, and M. H. Pereira. 2002. Role of the domestic chicken (Gallus gallus) in the epidemiology of urban visceral leishmaniasis in Brazil. Emerg. Infect. Dis. 8: 1480-1485.

Azevedo, A. C., S. M. Costa, M. C. Pinto, J. L. Souza, H. C. Cruz, J. Vidal, and E. F. Rangel. 2008. Studies on the sandfly fauna (Diptera: Psychodidae: Phlebotominae) from transmission areas of American Cutaneous Leishmaniasis in state of Acre, Brazil. Mem. Inst. Oswaldo Cruz. 103: 760-767.

Brazil, R. P. 2013. The dispersion of Lutzomyia longipalpis in urban areas. Rev. Soc. Bras. Med. Trop. 46: 263-264.

Brilhante, A. F.,. B. Sábio, and E.A.B. Galati. 2017. A New Species of Sand Fly, Psathyromyia elizabethdorvalae sp. $n$. (Diptera: Psychodidae: Phlebotominae), From Brazil. J. Med. Entomol. 54: 76-81.

Cesario, M., and M. Andrade-Morraye. 2008. Land-use and land-cover changes and the (re) emergence of diseases in Brazil. Source 11: 61-68.

Cesario, M., R. R. Cesario, and M. Andrade-Morraye. 2011. Environmental change and health impacts in Amazonia. IHDP Update 1:26-33.

De Oliveira, A.F.J., C.B.G. Teles, J. F. Medeiros, L.M.A. Camargo, and F.A.C. Pessoa. 2015. Description of Trichophoromyia ruifreitasi, a new phlebotomine species (Diptera, Psychodidae) from Acre State, Brazilian Amazon. ZooKeys 526: 65-73.

De Souza, N. A., R. D. Ward, J. G. Hamilton, C. P. Kyriacou, and A. A. Peixoto. 2002. Copulation songs in three siblings of Lutzomyia longipalpis (Diptera: Psychodidae). Trans. R. Soc. Trop. Med. Hyg. 96: 102-103.

Dujardin, J.-P., E. M. Torrez, F. L. Pont, D. Hervas, and D. Sossa. 1997. Isozymic and metric variation in the Lutzomyia longipalpis complex. Med. Vet. Entomol. 11: 394-400.

Forattini, O. P.1973. Entomologia Médica. vol. 4: Psychodidae. Phlebotominae. Leishmanioses. Bartonelose. Ed. Edgard Blucher \& Ed. USP, São Paulo, SP.

Galardo, A.K.R., C. D. Galardo, A. A. Santana, J.C.C. Mendes, F.R.A.D. Souza, J. P. Duarte, J. F. Saraiva, L.C.L. Pinna, R. W. Carvalho, A. P. Sales de Andrade Correa, et al. 2013. Primeira ocorrência de Lutzomyia (Lutzomyia) longipalpis Lutz \& Neiva, 1912 (Diptera: Psychodidae: Phlebotominae) no Estado do Amapá, Brasil. AGRIS 3: 179-183.

Galati, E. A. 2016. Phlebotominae (Diptera, Psychodidae) classificação, morfologia, terminologia e identificação de adultos. Departamento de Epidemiologia Faculdade de Saúde Pública. Apostila Disciplina HEP 5752 Bioecologia e Identificação de Phlebotominae 2016.(http://www.fsp.usp.br/ egalati/) (accessed 10 November 2016).

Garcia, A. L., R. Parrado, E. Rojas, R. Delgado, J. C. Dujardin, and R. Reithinger. 2009. Leishmaniases in Bolivia: Comprehensive review and current status. Am. J. Trop. Med. Hyg. 80: 704-711.

Gil, L. H., S. A. Basano, A. A. Souza, M. G. Silva, I. Barata, E. A. Ishikawa, L. M. Camargo, and J. J. Shaw. 2003. Recent observations on the sand fly (Diptera: Psychodidae) fauna of the State of Rondônia, Western Amazônia, Brazil: the importance of Psychdopygus davisi as a vector of zoonotic cutaneous leishmaniasis. Mem. Inst. Oswaldo Cruz. 98: 751-755.

Hamilton, J. G., R. D. Maingon, B. Alexander, R. D. Ward, and R. P. Brazil. 2005. Analysis of the sex pheromone extract of individual male Lutzomyia longipalpis sandflies from six regions in Brazil. Med. Vet. Entomol. 19. 480-488.

(IBGE) Instituto Brasileiro de Geografia e Estatística 2016. Cidades@ - Assis Brasil. (http://cidades.ibge.gov.br/v3/cidades/municipio/1200054) (accessed 01 December 2016)

Lainson, R., and E. F. Rangel. 2005. Lutzomyia longipalpis and the ecoepidemiology of American visceral leishmaniasis, with particular reference to Brazil: A Review. Mem. Inst. Oswaldo Cruz. 100: 811-827.

Le Pont, F., and P. Desjeux. 1985. Leishmaniasis in Bolivia. I. Lutzomyia longipalpis (Lutz \& Neiva, 1912) as the vector of visceral leishmaniasis in Los Yungas. Trans. R. Soc. Trop. Med. Hyg. 79: 227-231.

Le Pont, F., J. Mouchet, and P. Desjeux. 1989. Phlébotomes de Bolivie: VII. Répartition des deux morphotypes du phlébotome Lutzomyia longipalpis (Lutz et Neiva, 1912) (Diptera: Psychodidae) dans le piémont andin de Bolivie. Mem. Inst. Oswaldo Cruz. 84: 423-426.

Luna, E.J.A. 2002. A emergência das doenças emergentes e as doenças infecciosas emergentes e reemergentes no Brasil. Rev. Bras. Epidemiol. 5: 229-243.
Mooney, H., A. Larigauderie, M. Cesario, T. Elmquist, O. Hoegh-Guldberg, S. Lavorel, G. M. Mace, M. Palmer, R. Scholes, and T. Yahara. 2009. Biodiversity, climate change, and ecosystem services. Curr. Opin. Environ. Sustain. 1: 46-54.

(PAHO) Pan American Health Organization/World Health Organization 2016. Leishmaniases: Epidemiological Report in the Americas. PAHO/ WHO, 313 Washington, DC. (http://www2.paho.org/hq/index.php? option=com_docman\&task=doc_download\&Itemi d=\&gid=35859\&lang= en) (accessed 12 October 2016).

Pugedo, H., R. A. Barata, J. C. França-Silva, J. C. Silva, and E. S. Dias. 2005. HP: um modelo aprimorado de armadilha luminosa de sucção para a captura de pequenos insetos. Revista da Sociedade Brasileira de Medicina Tropical 38: 70-72.

Rangel, E. F., and M. L. Vilela. 2008. Lutzomyia longipalpis (Diptera, Psychodidae, Phlebotominae) and urbanization of visceral leishmaniasis in Brazil. Cad. Saúde Pública. 24: 2948-2952.

Sant'Anna, M. R., A. Nascimento, B. Alexander, E. Dilger, R. R. Cavalcante, H. M. Diaz-Albiter, P. A. Bates, and R. J. Dillon. 2010. Chicken blood provides a suitable meal for the sand fly Lutzomyia longipalpis and does not inhibit Leishmania development in the gut. Parasit. Vectors 3: 3.

Santos, D. R.D., A. C. Ferreira, and A. Bisetto Junior. 2012. The first record of Lutzomyia longipalpis (Lutz \& Neiva, 1912) (Diptera: Psychodidae: Phlebotominae) in the State of Paraná, Brazil. Rev. Soc. Bras. Med. Trop. 45: 643-645.

(SCTIE) Secretaria de Ciência e Tecnologia e Insumos Estratégicos. Ministério da Saúde. 2010. Doenças negligenciadas: estratégias do Ministério da Saúde. Rev. Saúde Pública. 44: 200-202.

(SEMA) Secretaria de Estado de Meio Ambiente do Acre 2010. Resumo educativo do Zoneamento Ecológico-Econômico do Acre: fase II. Secretaría de Estado de Meio Ambiente do Acre, Río Branco. (http://www.agencia.ac. gov.br/wp-content/uploads/2011/10/downloads_zee_resumo_educativo. pdf) (accessed 10 November 2016).

(SEPLAN) Secretaria de Estado de Planejamento do Acre 2013. Acre em números 2013. Secretaria de Estado de Planejamento, Departamento de Estudos e Pesquisas. (http://www.ac.gov.br/wps/portal/acre/Acre/estadoacre/sobre-o-acre/) (accessed 12 October 2016).

Shimabukuro, P.H.F., A. J. de Andrade, and E.A.B. Galati. 2017. Checklist of American sand flies (Diptera, Psychodidae, Phlebotominae): genera, species, and their distribution. ZooKeys 660: 67-106.

Souza, G. D., E. Santos, and J. D. Andrade Filho. 2009. The first report of the main vector of visceral leishmaniasis in America, Lutzomyia longipalpis (Lutz \&Neiva) (Diptera: Psychodidae: Phlebotominae), in the state of Rio Grande do Sul, Brazil. Mem. Inst. Oswaldo Cruz 104: 1181-1182.

(SVS) Secretaria de Vigilância em Saúde. Ministério da Saúde 2006. Manual de vigilância e controle da leishmaniose visceral. Ministério da Saúde: Secretaria de Vigilância em Saúde, Brasília. (http://bvsms.saude.gov.br/bvs/ publicacoes/manual_vigilancia_controle_leishmaniose_visceral.pdf) (accessed 10 November 2016)

(SVS) Secretaria de Vigilância em Saúde.Ministério da Saúde 2007. Manual de Vigilância da Leishmaniose Tegumentar Americana. Ministério da Saúde: Secretaria de Vigilância em Saúde, Brasília. (http://bvsms.saude.gov.br/bvs/publi cacoes/manual_vigilancia_leishmaniose_2ed.pdf) (accessed 10 November 2016).

Teles, C. B., R. A. Freitas, A.F.D. Oliveira, G. M. Ogawa, E.A.D. Araujo, J. F. Medeiros, F. A. Pessoa, and L. M. Camargo. 2013a. Description of a new phlebotomine species (Diptera: Psychodidae, Phlebotominae) and new records of sand flies from the State of Acre, northern Brazil. Zootaxa 3609: 85-90.

Teles, C.B.G., S. A. Basano, M. Zagonel-Oliveira, J. J. Campos, A.F.J.D. Oliveira, R.A.D. Freitas, J. F. Medeiros, F.A.C. Pessoa, A. Barral, and L.M.A. Camargo. 2013b. Epidemiological aspects of American cutaneous leishmaniasis and phlebotomine sandfly population, in the municipality of Monte Negro, State of Rondônia, Brazil. Rev. Soc. Bras. Med. Trop. 46: 60-66.

Teles, C.B.G.,. P.D.A.D. Santos, R. A. Freitas, A.F.J.D. Oliveira, G. M. Ogawa, M. S. Rodrigues, F. A. C. Pessoa, J. F. Medeiros, and L.M.A. Camargo. 2016. Phlebotomine sandfly (Diptera: Psychodidae) diversity and their Leishmania DNA in a hot spot of American Cutaneous Leishmaniasis human cases along the Brazilian border with Peru and Bolivia. Memórias do Instituto Oswaldo Cruz 111: 423-432. 